Language and Language Teaching Journal http://e-journal.usd.ac.id/index.php/LLT Sanata Dharma University, Yogyakarta, Indonesia

\title{
Infusing Culture in English Learning: An Attempt to Preserve Cultural Heritages in Jayapura Municipality, Papua
}

\author{
Wigati Yektiningtyas \& James Modouw \\ Cenderawasih University \& Ministry of Education and Culture, \\ Republic of Indonesia \\ wigati_y@yahoo.com \& james.modouw@kemendikbud.go.id \\ DOI: doi.org/10.24071/1lt.2017.200105
}

\begin{abstract}
Papua is rich with cultural heritages: hundreds of vernacular languages, tribes, folklores and other unique traditions. Unfortunately, these heritages are not recognized by the young generation anymore. Modernization, technology, and new comers are assumed as the background. As the capital of the province, Jayapura is the most influenced place for the changes. As an attempt to re-introduce and preserve the ancestor's cultural heritages, cultural infusion in learning English (as one type of learning) is regarded important. From seven tribes living in Jayapura, as the first step, Sentani is chosen as the priority. This paper discusses English learning materials by infusing Sentani culture. Folktales are chosen as learning materials for Elementary School students, malo ${ }^{1}$ for Junior High School students, the procedure to make kayilifa for Senior High Schoo students. This infusion hopes that young generation is able to learn English as well as to acknowledge one of the cultural heritages of Papua. They can be strongly rooted in their culture and respect others' culture.
\end{abstract}

Keywords: cultural infusion, cultural heritages, Sentani, English learning

\section{Introduction}

Besides its unique and beautiful geography, Papua is also rich with cultural heritages. There are about 275 vernacular languages (SIL, 2005), hundreds of tribes, thousands of folklores and other unique traditions spreading in the interior, north and south coastal areas. Unfortunately, these heritages are not recognized by especially young generation anymore. Modernization, technology, and new comers are assumed as the background. Television and gadget have distracted young generation from listening to parents' or grandparents' folktales telling. They also prefer modern dances, songs, films to traditional dances, paintings and carving. Without blaming the new comers to Papua or mixed marriage, their coming influences the use of local languages. Bahasa Indonesia is then used as the communication language. It is a common phenomenon that happens in Papua to see Sentani children cannot speak in Sentani language, Biak children do not recognize their folksongs, or Serui children that do not like eating their traditional food. 
As the capital of Papua province, Jayapura is the most influenced place for the changes. As an attempt to re-introduce and preserve the ancestor's cultural heritages in Jayapura, cultural infusion in learning English as one of learning materials is regarded important. There are seven tribes living in Jayapura: Tobati, Enggros, Kayu Batu, Kayu Pulau, Nafri, Skow and Sentani. As the first step, Sentani is chosen as the priority. Compared to other tribes, Sentani's folktales, oral poems, proverbs, folk songs, paintings, carving, traditional food, traditional architecture and dances are still preserved, especially by old generation and people who stay in islands in Sentani Lake and villages. It means that the data can still be obtained. There are also some schools that can utilize the learning materials.

Sentani society lives in some islands in Sentani Lake and villages in the edge of the lake, Jayapura. They speak in Sentani language with three dialects: Eastern, Central and Western Sentani dialects. In the islands, almost all children can speak Sentani Language (Hartzler, 1992). In some villages in the edge of Sentani Lake, only some children can speak Sentani language, and children who live in town cannot speak the language at all.

As English lecturers who focus on teaching literature and as education experts, we challenge ourselves to infuse these cultural heritages in English learning. This is also closely related to a twenty five year interaction with the Sentani people who complained about the young generation, especially those who live in town who are getting more ignorant to their cultural heritages. Also, from the experience with the students' practicum in Junior High School and Senior High School, it is proved that English learners in those schools are trapped with difficulties, boredom and cultural alienation.

We are dreaming to produce contextual learning that is friendly to the students. The main idea of this writing is how these Sentani cultural heritages can be infused and introduced/reintroduced to learners of English and why infusion is needed. This paper aims at exploring the Sentani culture that is suitable for the English learners: Elementary Schools, Secondary Schools and Senior High Schools and analizing the reasons why cultural infusion in learning English is needed. By having the contextual learning materials, it is hoped that young generation is able to learn English comfortably as well as acknowledge one of the cultural heritages of Papua. Hopefully they can be strongly rooted in their own culture and respect others' culture: they can act locally and think globally.

\section{Method}

This research is a qualitative one, obtaining the data from the field utilizing observation and interview with the participants. Since Sentani has various folklores, we had to select the genre of folklore that could be adopted for the English learning materials, The selection included an ondofolo, tribal chiefs, English teachers (Senior High School, Junior High School and Elementary School teachers), 6 students (2 High School students, 2 Junior High School students and 2 Elementary School students). The data selection prioritized on the data sources (which one could be adopted and which one could not be adopted), participants' availability, curriculum, and students' interest. From the discussion, it was 
concluded to adopt folktales for Elementary School learners, which was malo (bark painting) for Junior High School students, and kayi/ifa (traditional boats) for Senior High School students.

There were 5 participants who helped with the data of folktales, malo and kayi/ifa. The data were collected in January 2016 in Asei Island, Kampung Harapan and Kampung Waena. From the interview, five folktales were collected, seven malo paintings and the information about how to build kayi/ifa could be obtained as well. The data were collected in mixed language, Sentani and Indonesian languages.

After consulting the curriculum, the data was then translated into English based on the learning purposes. Folktales were rewritten and translated for Elementary School learning materials, using very simple vocabulary. Malo was designed as "descriptive" learning materials for Junior High School. Kayi/ifa were used as examples to explain procedural texts for Senior High School. The materials were then tried out in schools to check the students' responses and feedback. The materials was taught in SD YPK Pulau Asei, SMPN 12 Yoka and SMA PGRI Yabansai for six meetings.

\section{Discussion}

Stressing on the friendly, creative, innovative, motivating, encouraging and interesting classroom practice and after long observation and deep interviews with various people, finally folktale, malo, and kayi/ifa were chosen as the alternative materials to learn English in Elementary School, Junior High School and Senior High School.

Compared to adults, children are naturally good language learners. According to language acquisition theory, they can learn faster than adults. Psychologically, they are not stressed when they make mistakes as well. But it is important that they have to be exposed to natural learning setting and special teaching practice. In the case of Sentani children, they prefer materials closer to their tradition and socio-cultural life. One of the friendly materials for them is folktales. Mostly, Elementary School students like folktales since some of them listen to the parents'/grandparents' tale telling. Empirically, they were enthusiastic and motivated when they listened to Sentani folktales telling and read the folktales that have been rewritten in simple language. This is also the strong reasons of choosing folktales as teaching materials for teaching English for Elementary School students: their motivation, enthusiasm and emotional ties are the strong foundation for the students to learn. This is in line with Lazar's (2002) argument that teaching English using literature is motivating and encouraging since it has different style of writing and authentic use of language (esp. in local language), and it can be used as an access to cultural background and vocabulary expansion.

One example of adapted folktales used as English learning materials for grade VI in SD YPK Pulau Asei is "Ondofolo Habu". Originally, the tale is long and complicated and written in past tense but for the teaching purpose, the tale was written simply and shortly as follows.

Ondofolo Habu is a good leader in Asei.

He lives in big house with an obae. 
His wife is good too.

He has three children. He has one son and two daughters.

Ondofolo Habu likes hunting.

His wife likes cooking and painting malo.

The son likes fishing with his ifa

And the daugthers like gardening.

They are friendly. They like to help people.

People love them.

From the tale above the students learned (1) reading aloud, (2) retelling, (3) writing, (4) vocabulary and (5) Sentani culture.

Reading aloud helped the students to see the accurate connection of oral and printed language. It was good media for them to have reading and pronunciation practice. Having the similar sounds in Sentani phonology helped them in pronouncing some words like $v$ (in lives, love) $f$ (in wife), th (in three), $s h$ (in she, fishing), $g h$ (in daughters) easily. With continuous practice, they can become good speakers with perfect pronunciation. Reading aloud also sharpened other students' listening. They were drilled in sharpening memory, guessing the words' spelling, as well as inferring words' meaning. In classroom practice, after asking a student to read a sentence aloud, other students were asked to listen and asked them to retell what they had listened. It was a nice retelling practice. It was also awesome since some students retold the sentence in their own words, and interestingly they created their own sentences. The class was active since everybody in the class was competing to create their own sentences. For example, a student said "Ondofolo Habu is friendly", another said "Ondofolo Habu is happy". A student said "His son likes eating". Another said "His son likes drinking". The activities encouraged the students' enthusiasm and confidence.

In the writing activity, the students were asked to write a simple sentence using the vocabulary in the tale. This activity is not only helping the students in practicing using new words, but also practicing good English structure. When they were asked to write a sentence using the word "love", some sentences were created, i.e. "I love my father", "I love my mother", "I love my sister", "My brother loves me". Some students were good enough in identifying the subjectpredicate agreement, like "my brother" and "loves". Some creative students wrote the sentences on cards and gave them to their parents. Mrs. MO (30 years) once told us that she was happy and touched when her son gave her a card saying "I love my mother". This experience was good energy that improved the quality of relationship among children and parents. Besides, this also encouraged the parents to pay more attention to their children learning progress. For the students' vocabulary acquisition, games were used. The games focused on distinguishing noun, verb and adjective. This was also good media for the students to interact with teachers and classmates.

The short tale above was also a good medium to introduce Sentani culture. Some words like obae, malo, kayi, ifa were introduced to the students. Since SD YPK Pulau Asei Grade VI was a homogenous class, it was a bit easy to explain to them about the meaning and the function of obae (traditional meeting room, 
owned only by the big tribal chief), malo (bark painting that are only found in Pulau Asei) and ifa (boat used by men). According to the tribal chief of Pulau Asei, even though the words sound simple and ordinary, their infusion in teaching-learning process was important since outside of Pulau Asei, Sentani children cannot speak Sentani language anymore. The infusion is a prevention that helps the students to know and respect their culture. The tale also told about the labor division for father, mother, boy and girl. This helps the students to develop mutual respect to parents/sister/brother and male/female friends. They were introduced to the gender equality from the beginning as well. This also helps them to develop their character and personality.

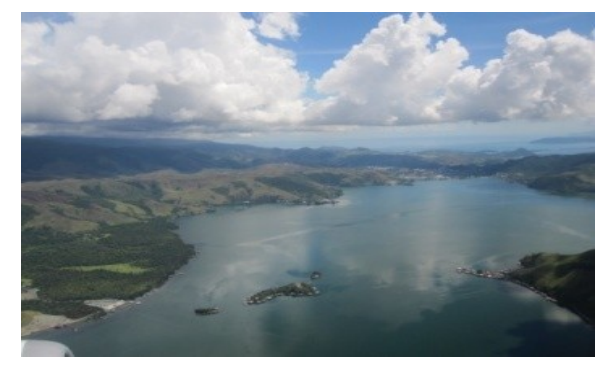

Picture 1. Asei Island, one of the tiny islands in Lake Sentani, a place where some cultural heritages can still be found. There is an Elementary School here where the teaching materials were tried out (March 31, 2016; Photo: Wigati Modouw)

Malo (bark painting) is a good materials to be discussed since in Papua, bark paintings are only found in Pulau Asei and they almost extinct as well. Not many people, especially young generation and people who live in town, recognize them. Discussing malo means introducing one of Papuan cultural heritages. When the materials was tried out in grade 12 of SMP 12 Yoka, there were three steps used. They are (1) displaying the bark paintings to the classroom and giving short reading about it, (2) asking a malo painter to come to the class to explain the process of painting malo using Indonesian, and (3) taking the students to Asei Pulau. Empirically, using malo as the teaching materials is the most interesting one since the students were very active interacting with their classmates, teacher, painters and people in the island. The teaching focus was description utilizing speaking and writing skills.

In step one, the teacher brought some malo paintings to classroom and give an example of short description of malo painting as follows,

Malo painting uses bark as the canvas. Traditionally it was only female who painted malo. But after Word Was II, malo was also painted by male (Howard, 2000). Nowadays, malo paintings are only found in Asei Island. Malo paintings utilize barks from various trees, i.e. kombouw, matoa, and sukun tree. But kombouw tree is the favourite one. It has good texture. Malo is made manually. The bark is cleaned, pounded and dried under the sun. 
After it is dried, the painter paints on it using natural pigment. Sentani people only use three colors. They are white from lime, black from charcoal, and red from clay or plants. The motives are animals as their totems and their fragments.

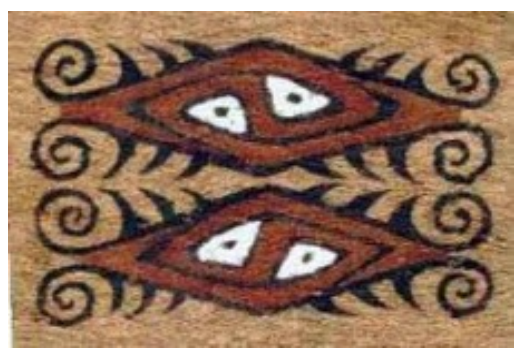

Picture 2. Malo painting (Agus Ongge's private collection)

The students were given time to see and learn the painting: the shape, material, motives, colors. Then the students were given time to read the description. From the experience, they could produce interesting sentences in written and orally since they had time to see, touch, learn and read the article about malo.

These activities were enriched by the presence of a painter who explained and demonstrated how to paint it (step 2). The students are motivated and freely asked the painter, i.e. "how many days you can finish a painting?", "why do you only use three colours?", "why only red, white, and black?", "is it ok to use other colors?", "when did you start painting malo?", "who taught you?". The conversation was done in Indonesian but it helped the students in widening their knowledge about malo. Then in step 3, they students were brought to the island in a scientific tour. They were happy to go there. In the island they could see the process of pounding and drying the bark. They could also see some painters painted different kinds of motives. In the island they interacted not only with the painter but also with the tribal chief and Island people. They creatively asked various questions, i.e. "how to cut the tree down?", "what kinds of tree used for malo?", "who cut the tree?", "how many people cut the tree?", "who brought the tree from the woods to the village?", "how many motives of malo?", "how many colors used for painting malo?", "do you sell malo?", "where do you sell it", "who buy it?". Afer the site visit, in class, the students can confidently do writing and speaking about malo descriptively, helped by the questions they raised to the teachers, painters, elders, and tribal chiefs.

Related to natural disaster in Papua like flood, bush fire and landslide, choosing the materials about the process of building ifa/kayi (Sentani traditional boat) is interesting. It deals with how people cutting down trees as the main materials to build the boat. Sentani people had their own wisdom in choosing the trees and the method of cutting them down from which the students can learn that preserving nature is important and illegal logging is not appropriate.

Focusing on speaking and writing skill, the materials was tried out in SMA PGRI Waena. The students were challenged to tell and write the process of 
building kayi/ifa. Kayi is a Sentani traditional boat used by women in Sentani for fishing and carrying harvest from the garden. It is also used for common transportation. While ifa is only used for men to fish. The shape is smaller than kayi. In the past, both kayi and ifa and also oar were decorated with carved ornaments in various motives. This art is called ohomo. By choosing kayilifa in English language classroom, the students did not only learn the language, but also the local wisdom beyond the boat building and other traditional arts.

The teaching activities were divided in two steps. Step one was conducted in classroom. The students were given time to watch a video on the process of building boat cooperatively, starting from the process of cutting a tree down in the woods (picture 3), making the boat cooperatively in the woods (picture. 4), and pulling the boat from the woods to the village (picture 5).

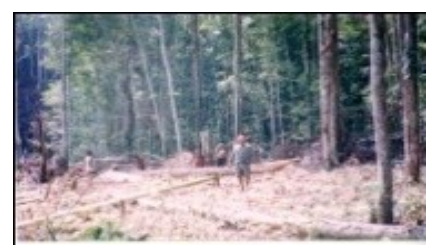

Picture 3. Cutting the trees down in the woods

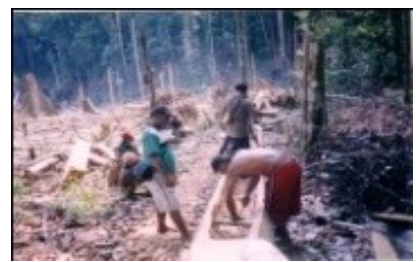

Picture 4. Building the boat by making the big hole on the tree in the woods

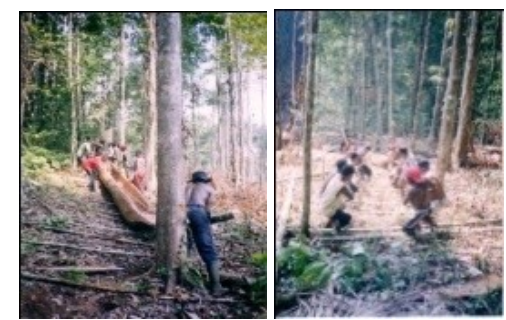

Picture 5. Pulling the boat from the woods to the village

While watching the video, the students were asked to write free simple sentences about the video they watched, helped by some vocabulary. In the beginning of the class, the students were informed that they had to write a short paragraph on the process of building a traditional boat guided by the video. The information in the video was enriched by the students' visit to Asei Island (Step 2).

In the village, the students could see the process of cleaning and carving the boat with various motives. In the village, students were able to develop their knowledge of building boat they watched on the video by asking some questions to the builders, carvers, elders, tribal chiefs i.e. "what tree was used to build a boat?", "how many people involved in cutting the tree down?", "how long is the 
process of building a boat in the woods?", "how do you carry the boat to the island?", "does each tribe have its own motives?", "does each motif have meaning?", "are female allowed to carve too?", "what colours are used for carving?", "do you sell the boat?", etc.

In classroom, the students and the teacher discussed various things: the essence of the video, the result of interviews in the island and the project they have to do. Giving time for the students to watch the video and free interpretation about the video's essence and taking them to the island motivated them to create a short composition creatively. They could also present their writing supported by pictures and video they made themselves in the island. They said that they like the learning method since they can learn the language in a different way and the culture without burden. The elders in the island were also happy seeing young generation learn their culture.

\section{Why Infusing Culture in English Learning?}

Having emotional tie for the students in dealing with the teaching materials is the first reason of infusing culture in English learning for Elementary School, Secondary High School and Senior High School students in Jayapura Municipality. The students were happy learning their own tradition. They learned about themselves. This motivated them to learn English, even when the materials are made a bit difficult (see also Lazar, 2002). Various facts have proved that students in Jayapura have been alienated from the materials in their textbooks. It is a bit hard for them to learn folktales or culture from other tribes, since they are not familiar with the natural environment, places and cultural objects. The different concepts of houses, transportation, clothes, etc create alienation that hinder them in learning English as well.

By infusing their own culture in English learning, preserving culture could be involved at once. Empirically, from the folktale given in class, they students were motivated to seek more tales, ask more details about malo, kayi and ifa and other cultural heritages from their parents/grandparents. Two participants, Mrs. MO (66 years) and Mr. AO (72 years) said that since some parents/grandparents did not know much about their culture, they asked their friends, tribal chief, or ondofolo. Interestingly, the people in the island were busy preparing themselves for the possible questions from the children/grandchildren. Thus, the children can learn more culture and the parents relearn their culture as well. The tribal chief said that it was also a good "awakening" for the people: they were finally aware that they have been ignorant of their own cultural heritages. From the children, they sharpened their cultural awareness (Tomalin, 2014).

Infusing culture in English learning is an attempt of promoting local wisdom for young generation. From malo and kayi/ifa they could learn how to cut down trees and respect nature since they were informed by the artists and the elders that Sentani people were very careful in cutting down trees. They always selected trees that could be utilized and if they cut it down, they planted a new tree as the replacement. From these materials, they did not only learn English language but also learned about ecological sensibility: learned how to conserve their natural surroundings. 
Involving culture in English classroom can be used as character building media. From the moral lessons in the folktale(s), malo and kayi/ifa, the students can learn the importance of being proud of their identity, being honest, helpful, cooperative, loving, brave, discipline, hard working, and respectful to God, people and nature. Using culture in English learning is important to sharpen the students' identity as well. In the era of globalization there are some problems with uprooted generation who are ashamed of their own culture. Culture in classroom helps them feel proud of their own culture.

\section{Conclusion}

From the culture infusion in English learning classroom in Jayapura Municipality, the students did not only learn English language but they were also motivated to learn Sentani culture from which they could also learn other cultural heritages, local wisdom, and identity. This can also be used as character building and cultural preservation.

Involving artists, parents, elders, and tribal chiefs in classroom activities did not only make the teaching-learning process unique, interesting, and motivating, but also develop their cultural awareness. This involvement also made them aware that education is not only schools' responsibility, but theirs as well. It is true that infusing culture in English language classroom did not change the students' character instantly and automatically. It needs time. But empirically, from the students', parents', elders', tribal chiefs' responses, the infusion will slowly help them to be proud of their own cultural identity and motivated to preserve culture for the next generation.

It is suggested that adoption of other cultural heritages for English teachinglearning materials, involvement of parents, elders, tribal chief and cultural teaching methodology can be widely and comprehensively developed.

\section{References}

Danandjaja, James. (2002). Folklor Indonesia: Ilmu gosip, dongeng, dan lainlain. Jakarta: Pustaka Utama Grafiti.

Hartzler, Margaret. 1992. "A brief phonology of the Sentani", Afeu year III no. 4. Jayapura: Percetakan Universitas Cenderawasih.

Lazar, Gillian. (2002). Literature and language teaching: A guide for teachers and trainers. Cambridge: Cambridge University Press.

Omrod, J.E. (2009). Psikologi pendidikan membantu siswa tumbuh dan berkembang. Jakarta: Erlangga.

Santrok, J.W. (2009). Educational Psychology. New York: McGraw Hill Int.

Tomalin, B. 2014. "Making Culture Happen in English Language Classroom". www.teachingenglish.org.uk

Yektiningtyas-Modouw, W. (2011). Helaehili dan Ehabla: Fungsinya dan peran perempuan dalam masyarakat Sentani Papua. Yogyakarta: Adicita Karya Nusa.

Yektiningtyas-Modouw, W., et. al. (2009). "Folklor Sentani: Panggalian kembali kearifan lokal masyarakat" (Laporan Hibah Kompetitif Penelitian Sesuai Prioritas Nasional Batch IV). 